\title{
SLIDE SCREENING TEST FOR GLANDULAR FEVER
}

\author{
BY \\ W. BRUMFITT AND F. O'GRADY \\ From Southern Command (Leishman) Laboratory, Aldershot, Hants
}

(RECEIVED FOR PUBLICATION OCTOBER 16, 1956)

The modification of Paul and Bunnell's (1932) original haemagglutination test for glandular fever described by Davidsohn (1937) which is used in its original or further modified forms in most laboratories, while simple to perform, is time consuming both in execution and in the delay before reading. Butt and Foord (1935) had claimed that, if sera which showed a positive Paul-Bunnell titre were mixed with sheep cells in a hanging drop preparation, agglutination was immediate. Following this observation, Straus (1936) developed rapid slide and tube tests. Similar slide screening tests have been used with considerable success by Rappaport and Skariton (1949), Moloney and Malzone (1949), and Vaughn (1951), the number of false results either negative or positive being small or absent in their experience. In these reports, however, the majcrity of patients were definitely not suffering from glandular fever. It appeared of interest, therefore, to compare the results of the very simple test described by Vaughn with the conventional Davidsohn absorption technique in the circumstances in which the test is most commonly applied in practice, that is, in a series of cases in which the clinical diagnosis was glandular fever. The results in both the serologically confirmed and unconfirmed cases are included.

\section{Materials "and Methods}

A total of 180 consecutive cases was examined and these were divided into two groups, one of 50 and one of 130. In the first 50 cases a drop of unheated, undiluted serum was mixed on a slide with one drop of a $10 \%$ saline suspension of washed sheep cells and rocked gently for one minute. Agglutination within this time was reported as positive. In the second group of cases, rocking of the slide was continued for 180 seconds and the actual time taken for gross macroscopic agglutination to occur was recorded. In both groups, the remaining serum was then inactivated and examined by Davidsohn's (1937) absorption technique using doubling dilutions from $1: 5$. A titre of $1: 80$ after guinea-pig kidney absorption was regarded as positive.

\section{Results}

The results in the first group of 50 cases are shown in Table I. Of the 12 cases which failed to show agglutination in the screening test in less than one minute, none showed a Paul-Bunnell titre of more than 1:40 after guinea-pig kidney absorption.

TABLE I

COMPARISON OF SCREENING TEST AND PAUL-BUNNELL TITRE BEFORE AND AFTER GUINEA-PIG KIDNEY ABSORPTION

\begin{tabular}{|c|c|c|c|c|c|c|c|c|c|c|}
\hline \multirow{2}{*}{$\begin{array}{c}\text { Screening } \\
\text { Test }\end{array}$} & \multicolumn{9}{|c|}{ Number of Patients with Paul-BunnellTitre of: } & \multirow{2}{*}{ Total } \\
\hline & $\begin{array}{l}20 \text { or } \\
\text { Less }\end{array}$ & 40 & 80 & 160 & 320 & 640 & 1,280 & $|2,560|$ & $\mid 5,120$ & \\
\hline $\begin{array}{l}\text { Positive } \\
\text { Negative }\end{array}$ & $\begin{array}{l}3 \\
8\end{array}$ & $\begin{array}{l}3 \\
3\end{array}$ & $2^{B}$ & $\left|\begin{array}{l}\text { efore } \\
8 \\
0\end{array}\right|$ & $\begin{array}{l}a b s o \\
8 \\
0\end{array}$ & $\left|\begin{array}{l}4 \\
0\end{array}\right|$ & $\begin{array}{l}5 \\
0\end{array}$ & \begin{tabular}{l|l}
4 & \\
0 & $\mid$
\end{tabular} & $\begin{array}{l}1 \\
0\end{array}$ & $\begin{array}{l}38 \\
12\end{array}$ \\
\hline $\begin{array}{l}\text { Positive } \\
\text { Negative }\end{array}$ & $\begin{array}{r}6 \\
10\end{array}$ & $\begin{array}{l}5 \\
2\end{array}$ & $\begin{array}{l}\mathbf{0}^{A} \\
0\end{array}$ & $\begin{array}{c}e r \\
6 \\
0\end{array}$ & $\begin{array}{l}7 \\
0\end{array}$ & $\begin{array}{l}\text { tion } \\
4 \\
0\end{array}$ & $\begin{array}{l}4 \\
0\end{array}$ & $\begin{array}{l}5 \\
0\end{array}$ & $\begin{array}{l}1 \\
0\end{array}$ & $\begin{array}{l}38 \\
12\end{array}$ \\
\hline
\end{tabular}

Thirty-eight cases were positive on screening and, of these, 11 had Paul-Bunnell titres of less than 1:80 after guinea-pig kidney absorption. A comparison of the time taken for agglutination to occur in the screening test and the Paul-Bunnell titre, before and after absorption with guinea-pig kidney, in the remaining 130 cases is given in Tables II and III. There is a relation between the results of the screening test and Paul-Bunnell titre, and, although rapid agglutination may be associated with low titres, significant titres do not occur in those negative to the screening test.

Examination of the overall results in the total of 180 cases shows that, of the sera failing to show macroscopic agglutination within one minute, one had a Paul-Bunnell titre before absorption of $1: 160$

TABLE II

COMPARISON OF PAUL-BUNNELL TITRE BEFORE GUINEA-PIG KIDNEY ABSORPTION WITH TIME OF AGGLUTINATION IN SLIDE SCREENING TEST

\begin{tabular}{|c|c|c|c|c|c|c|c|c|c|c|}
\hline \multirow{2}{*}{\multicolumn{2}{|c|}{$\begin{array}{l}\text { Screening Test } \\
\text { for Agglutination } \\
\text { (Time in Sec.) }\end{array}$}} & \multicolumn{9}{|c|}{$\begin{array}{c}\text { Number of Patients with Paul-Bunnell Titre } \\
\text { before Absorption of: }\end{array}$} \\
\hline & & 20 or & 40 & 80 & 160 & 320 & 640 & 1,280 & 2,560 & 5,120 \\
\hline $\begin{array}{l}20 \text { or less } \\
21-40 \\
41-60 \\
61-120 \\
120\end{array}$ & $\begin{array}{ll}\ldots & \ldots \\
\cdots & \cdots \\
\cdots & \cdots \\
\cdots & .\end{array}$ & $\begin{array}{r}0 \\
0 \\
2 \\
9 \\
28\end{array}$ & $\begin{array}{l}0 \\
0 \\
3 \\
5 \\
7\end{array}$ & $\begin{array}{l}0 \\
8 \\
3 \\
2 \\
3\end{array}$ & $\begin{array}{l}4 \\
7 \\
5 \\
1 \\
0\end{array}$ & $\begin{array}{l}2 \\
9 \\
1 \\
0 \\
0\end{array}$ & $\begin{array}{l}6 \\
2 \\
1 \\
0 \\
0\end{array}$ & $\begin{array}{l}4 \\
4 \\
0 \\
0 \\
0\end{array}$ & $\begin{array}{l}4 \\
1 \\
0 \\
0 \\
0\end{array}$ & $\begin{array}{l}5 \\
1 \\
1 \\
0 \\
0\end{array}$ \\
\hline
\end{tabular}


TABLE III

COMPARISON OF PAUL-BUNNELL TITRE AFTER GUINEA-PIG KIDNEY ABSORPTION WITH TIME OF AGGLUTINATION IN SLIDE SCREENING TEST

\begin{tabular}{|c|c|c|c|c|c|c|c|c|c|c|}
\hline \multirow{2}{*}{\multicolumn{2}{|c|}{$\begin{array}{l}\text { Screening Test } \\
\text { for Agglutination } \\
\text { (Time in Sec.) }\end{array}$}} & \multicolumn{9}{|c|}{$\begin{array}{l}\text { Number of Patients with Paul-Bunnell Titre } \\
\text { after Absorption of: }\end{array}$} \\
\hline & & $\begin{array}{l}20 \text { or } \\
\text { Less }\end{array}$ & 40 & 80 & 160 & 320 & 640 & 1,280 & 2,560 & 5.120 \\
\hline $\begin{array}{c}20 \text { or less } \\
21-40 \\
41-60 \\
61-120 \\
120\end{array}$ & $\begin{array}{l}\cdots \\
\cdots \\
\cdots \\
\cdots\end{array}$ & $\begin{array}{r}0 \\
4 \\
6 \\
19 \\
38\end{array}$ & $\begin{array}{l}0 \\
3 \\
3 \\
0 \\
0\end{array}$ & $\begin{array}{l}2 \\
6 \\
1 \\
0 \\
0\end{array}$ & $\begin{array}{r}3 \\
11 \\
3 \\
0 \\
0\end{array}$ & $\begin{array}{l}3 \\
2 \\
2 \\
0 \\
0\end{array}$ & $\begin{array}{l}5 \\
3 \\
0 \\
0 \\
0\end{array}$ & $\begin{array}{l}5 \\
2 \\
0 \\
0 \\
0\end{array}$ & $\begin{array}{l}2 \\
1 \\
0 \\
0 \\
0\end{array}$ & $\begin{array}{l}5 \\
0 \\
1 \\
0 \\
0\end{array}$ \\
\hline
\end{tabular}

and six a titre of $1: 80$. However, after absorption with guinea-pig kidney none of these gave a iitre of more than $1: 40$. On the other hand, of the total of 111 sera positive on screening, 11 had titres of $1: 40$ or less before guinea-pig kidney absorption, and 27 had titres of $1: 40$ or less after absorption.

\section{Discussion}

Vaughn (1951) found absolute correlation between slide agglutination occurring in less than 60 seconds and a Paul-Bunnell titre of 1:64 or more. Although we have not found this to be true in every case, it is nevertheless clear that the screening test is of value in excluding cases which will prove negative to the Paul-Bunnell test.

The advisability of regarding one minute as the limiting period for positive results in the screening test is emphasized. For example, in Table III, if 40 seconds were taken as the critical period, the screening test would fail to exclude seven of the sera with Paul-Bunnell titres of $1: 40$ or less after absorption, but would exclude six sera having titres of more than $1: 160$.

It is clear, therefore, that sera failing to give macroscopic agglutination in this test after one minute may justifiably be regarded as negative, but of those positive at this time about one-third fail to show titres of more than 1:80 after guinea-pig kidney absorption.
Because the patients in the present series were all clinically diagnosed as glandular fever, and because previous workers have regarded false positive results in the screening test to be very rare, the possibility must be considered that this test is superior to the Paul-Bunnell test in the recognition of milder cases. We have shown elsewhere that the Paul-Bunnell titre is related to the number of circulating abnormal mononuclear cells and that in genuine cases at least $5 \%$ of abnormal cells are present in the first week, those described as Type I cells being aiways represented (Brumfitt and $\mathrm{O}^{\circ}$ Grady, 1957). In those of the present series in which the Paul-Bunnell test was negative, no relationship between the presence of abnormal cells and the slide screening test could be shown. At present, therefore, the value of the test is restricted to separating those cases which will prove negative to the Paul-Bunnell test.

\section{Summary}

Sera from 180 patients who were suspected, on clinical grounds, of having glandular fever were examined by a slide screening test and by the Davidsohn absorption technique and the results compared.

Sera failing to produce haemagglutination in the slide test in 60 seconds may be regarded as negative. On the other hand, of the sera which showed agglutination within 60 seconds one-third of the cases failed to show titres of more than 1:80 after guinea-pig kidney absorption.

It is suggested that 60 seconds is the optimal time to differentiate between positive and negative sera

\section{RFFERENCES}

Brumfitt, W., and O'Grady, F. (1957). To be published. Butt, E. M., and Foord, A. G. (1935). J. Lab. clin. Med., 20, 538. Davidsohn, I. (1937). J. Amer. med. Ass., 1ü8, 289.

Moloney, W. C., and Malzone, L. (1949). Blood, 4, 722.

Paul, J. R., and Bunnell, W. W. (1932). Amer. J. med. Sci., 183, 90.

Rappaport, F., and Skariton, M. (1949). Amer. J. clin. Path., 19, 665. Straus, R. (1936). Ibid., 6, 546.

Vaughn, J. (1951). Journal of Clinical Pathology, 4, 104. 